\title{
A new epitype specimen for Campanula peshmenii Güner
}

\section{Campanula peshmenii Güner için yeni bir epitip örneği}

\author{
Research Article
}

Birol Mutlu* and Şükrü Karakuş

İönü University, Faculty of Science and Arts, Department of Biology, Malatya, Turkey.

\section{A B S TR AC T}

n this study, a new type (epitype) specimen for Campanula peshmenii Güner is determined. Detailed description and conservation status of this species are given. This study also contained SEM images and photographs of pollen, seed, hairs of corolla, and stylus, holotype and epitype specimen, habitat, flowering, and fruiting shape of habitus.

\section{Key Words}

Campanulaceae, Campanula, ICBN, pollen, seed, SEM, taxonomy, type.

\section{ÖZET}

u çalışmada Campanula peshmenii Güner için yeni bir tip (epitip) örneği belirlenmiştir. Bu türe ait ayrıntılı bir morfolojik tür tanımı ve tehlike kategorisi verilmiştir. Ayrıca bu çalışmada, polen, tohum, korolla tüyü, sitilus SEM görüntüleri ile holotip ve epitip örnekleri, habitatı, çiçekli ve meyveli durumlarının fotoğrafları verilmiştir.

\section{Anahtar Kelimeler}

Campanulaceae, Campanula ICBN, polen, tohum, SEM, taksonomi, tip.

Article History: Received: Oct 11, 2015; Revised: Nov 22, 2015; Accepted: Nov 26, 2015; Available Online: Dec 30, 2015.

DOI: $10.15671 /$ HJBC.20154315985

Correspondence to: B. Mutlu, İnönü University, Faculty of Science and Arts, Department of Biology, Malatya, Turkey. 


\section{INTRODUCTION}

Campanula L. is the largest genus of the Campanulaceae family, involving approximately 420 species and distributed from Northern hemisphere to Mediterranean Region $[1,2]$. The genus in Turkey consists of 133 taxa ( 7 subspecies and 3 varieties). Campanula peshmenii Güner is one of the endemic species for the genus Campanula of which 66 species are endemic in Turkey $[3,4]$.

Specimens of C. peshmenii were firstly collected by Hasan Peşmen in 1971 (Figure 1). Hasan Peşmen, the first head of Botany Department in Hacettepe University, died in a car accident in 1981. Twelve years after the first collection, this specimen was published as a new species by Adil Güner [5]. Campanula peshmenii has only one type specimen (as holotype) in HUB herbarium. This specimen is inadequate to describe flowers colours, fruit, and seed morphologies. Therefore, new type specimen has been described as an epitype for $C$. peshmenii.

\section{MATERIAL AND METHODS}

Many fruiting and flowering specimen collected from type locality. Collected specimens were prepared as herbarium specimens according to Bridson and Forman [6]. These specimens that assigned a separate inventory number are kept in INU herbarium. Flora of Turkey and papers of new species are especially used to identify the specimens [3,5,7-9]. Type specimen of $C$. peshmenii was examined in HUB herbaria. Morphological characters of studied specimens were examined by using a binocular stereoscopic microscope. SEM micrographs of seed and pollen samples, coated with gold, were obtained by using an EVO 40XVP (LEO Ltd., Cambridge, UK) scanning electron microscope at an accelerating voltage of $20 \mathrm{kV}$.

\section{RESULTS AND DISCUSSIONS}

Campanula peshmenii has only holotype specimen in HUB herbarium (Figure 1). This specimen is inadequate to describe flowers colours, fruit, and seed morphologies. Colour of corolla in the holotype specimen was not clear. If collected specimens are not properly dried, colour of the corolla changes to light brown when dried. Outer surface of corolla also is covered densely with white tector hairs. Colour of the corolla looks milky white because of these reasons. Colour of corolla was described as "lactae" (milky white) in the protolugue of the C. peshmenii [5]. In this study, the colour of corolla of $C$. peshmenii was described as lavender blue (Figures 2,3).

Capsule, pore of capsule and seed properties of $C$. peshmenii, which was collected in the late of July, were absent in the type specimens and this situation was indicated in the protolugue [5]. Therefore, new type specimen, which has clear colour of the corolla, capsule, pore of capsule and seed, was described as an epitype and four isoepitype for $C$. peshmenii according to "Article 9.8" and "Rec. 9C1" in ICBN [10] (Figure 2)

Number of stigma pairs of C. peshmenii was determined as only three in its protologue; but, four pairs of stigma in some flowers of $C$. peshmenii were observed in this study.

Pollen properties of $C$. peshmenii species are mostly oblate-sphaeroidal and triporate, tectums are scabrate and Amb axes are circular (Figure 4). These properties are mostly observed in species of the genus [11]. Two exine sculpture types (granulate scabrate and regulate-scabrate) were described in some species of genus Campanula by Erkara et al. [11]. The exine sculpture type is regulate-scabrate in $C$. peshmenii. There are 95110 spinules in $1 \mu \mathrm{m}^{2}$.

Two seed surface types were described by Akçin [12] as reticulate (type1) and striate (type2) in some Campanula (Subgenus Campanula and Rapunculus) species. Testa shapes of these subgenera (excluding C. olympica Boiss.) are mostly type2. Campanula peshmenii included in the subgenus Campanula and show the seed morphology (fusiform shape and interrupted striate testa) of this subgenus (Figure 4).

\section{Taxonomy}

Campanula peshmenii Güner, in Notes Roy. Bot. Gard. Edinburgh, 41:287 (1983).

(Subgenus Campanula, Section Rupestres (Boiss.) Charadze) 


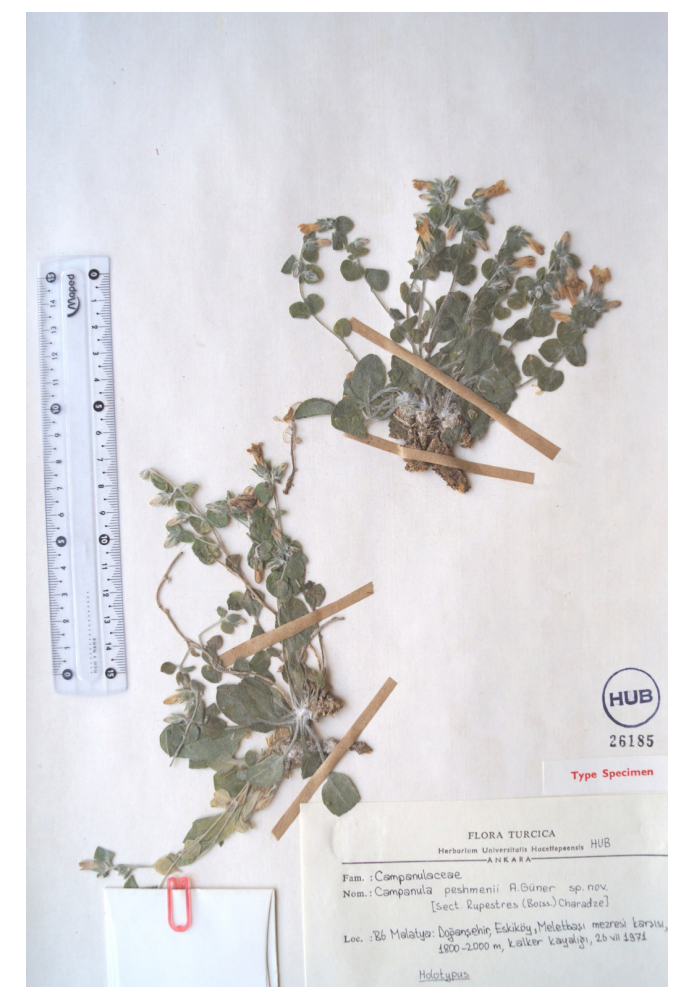

Figure 1. Holotype specimen of Campanula peshmenii Güner in HUB herbarium (Peşmen 2717).

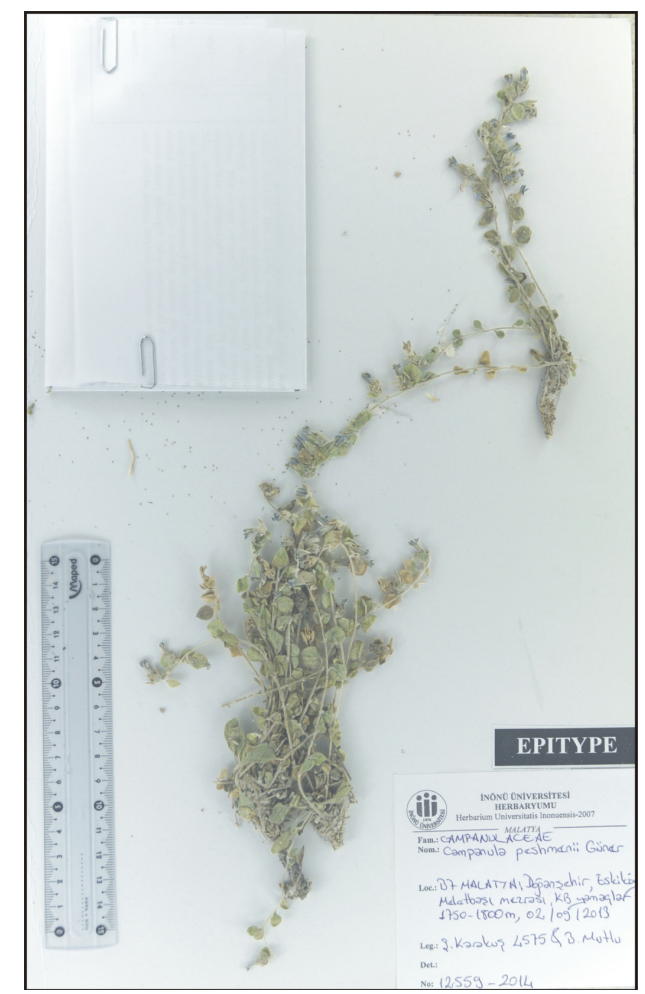

Figure 2. Epitype specimen of Campanula peshmenii Güner in INU herbarium (Karakuş \& Mutlu 4575). 


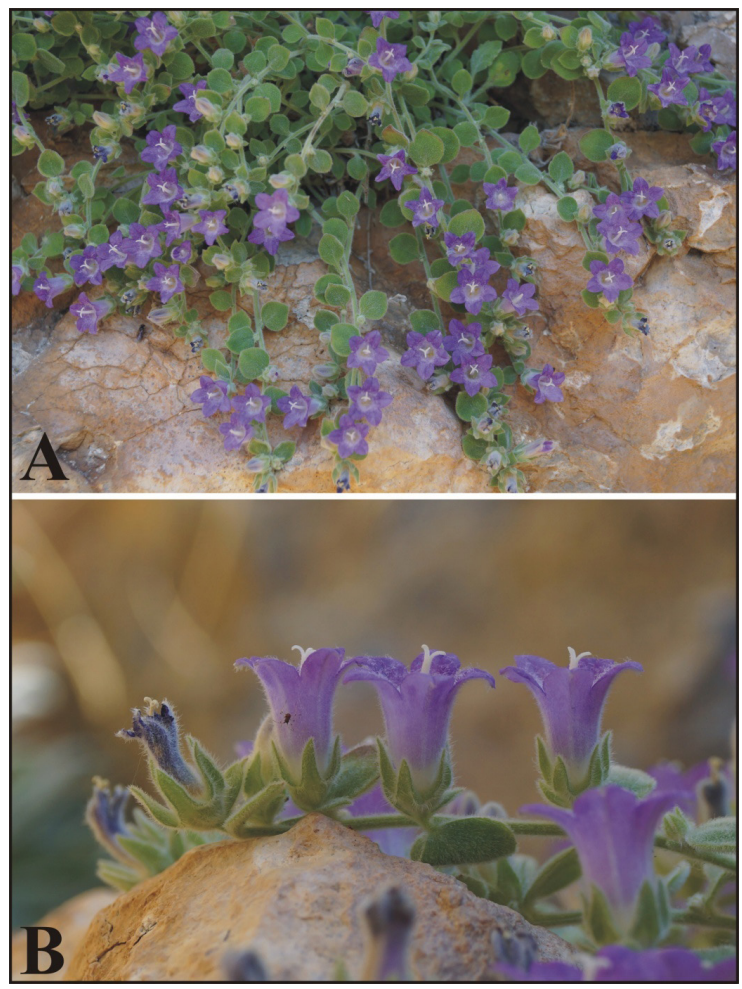

Figure 3. Flowering plants of Campanula peshmenii Güner. (A) habitat, habitus, three and four pairs stigma; (B) flowers, (Karakuş \& Mutlu 4488) (photo: B. Mutlu).

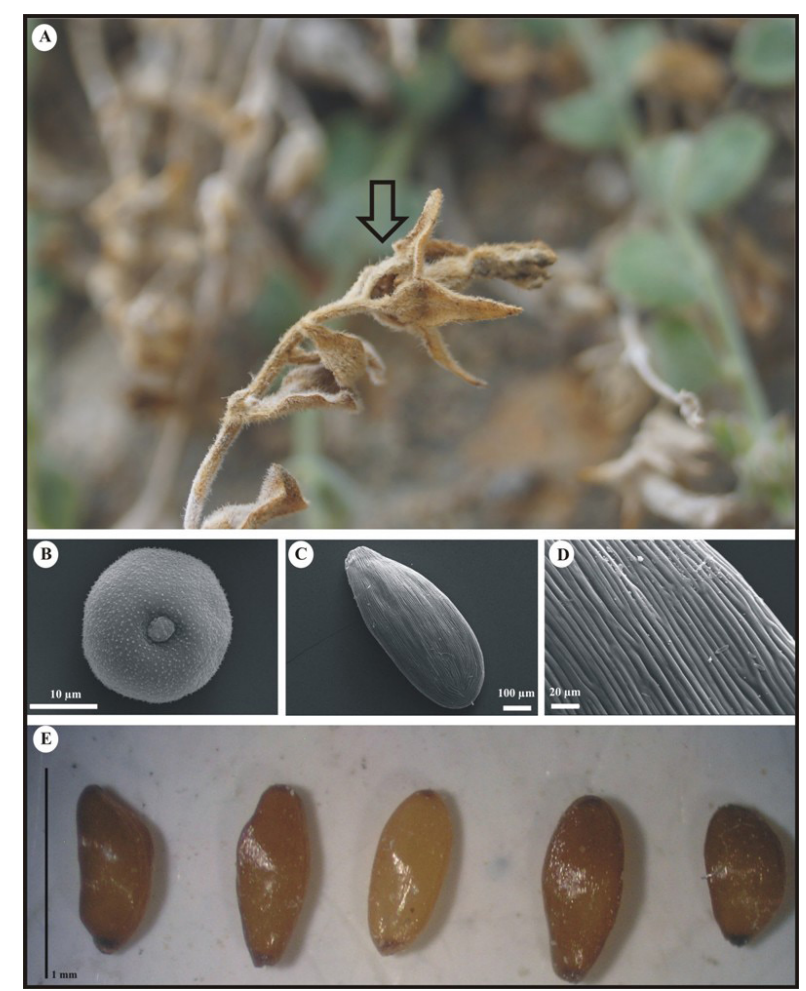

Figure 4. Photograph (A), SEM images (B-D) and stereoscopic microscope view (E) of Campanula peshmenii Güner. (A) fruit; (B) pollen; (C-E) seed and (D) seed surface (Karakuş \& Mutlu 4575) (photo: B. Mutlu). 
Holotype: [Turkey] B6 Malatya: Doğanşehir, Eskiköy village, slopes of opposite side of Meletbaşı Hamlet, limestone rocks, 1800-2200 m, 26 vii 1971, H. Peşmen 2717! (HUB 26185; photo ANK, E) (Figure 1).

Epitype (designated here): [Turkey] B6 Malatya: Doğanşehir, Eskiköy village, slopes of opposite side of Meletbaşı Hamlet, limestone rocks, 17001800 m, 02 ix 2013, Ş. Karakuş 4575 \& B.Mutlu [INU (INU 12559-2014)]. isoepitype: ibid., Ş.Karakuş 4575 \& B.Mut/u [INU (INU 12560-2014)]; ibid., Ş.Karakuş 4575 \& B.Mutlu [HUB (INU 12561-2014)]; ibid., S..Karakuş 4575 \& B.Mutlu [ANK (INU 125622014)] (Figure 2).

\section{Description}

Dwarf caespitose chasmophytic perennial, withouth sterile shoots. Stems ascending, 6-15 $\mathrm{cm}$, with thick scaly collar at base, woody caudex, unbranched 3-8 leafy, tomentose hispid (hairs 0.7-1.3 mm). Flowering stems numerous, prostrate, 9-12 cm long, usually simple, hirsute-tomentose, leafy throughout. Basal leaves, broadly elliptic or ovate, $10-20 \times 6-14 \mathrm{~mm}$, entire or shallowly crenate, crisply tomentellous; petiole $10-25 \mathrm{~mm}$. Cauline leaves ovate to obovate, to 6-13 $\times$ 4-10 $\mathrm{mm}$, most often entire, crisply tomentellous, sessile or with petiole $0.5-2 \mathrm{~mm}$. Inflorescence racemose, 3-6-flowered, terminal flower opening first. Flowers patent, pedicels to $3 \mathrm{~mm}$. Calyx lobes triangular-lanceolate, 4-5 x 2-2.5 mm, erect, acute, tomentose. Appendages inconspicuous. Corolla lavender blue, cylindrical-infundibular, 8-13 mm, lobes 2-3 mm, tomentose outside, divided to $1 / 4$ into triangular-ovate, acute lobes. Stamen (4-) 4.5-5 mm; filiform part of filament 0.5-0.6 mm; base oblong-elliptic, 1-1.5 x $1.0 \mathrm{~mm}$ ciliate. Anthers $3.5-4 \mathrm{~mm}$, shorter than style. Receptacle glabrous. Style $8-9 \mathrm{~mm}$, included in corolla tube. Stigma 3(-4), 0.8-1.2 mm. Capsule $(-3.5) 4-5(-6) \times 3 \mathrm{~mm}$, erect turbinate, opening by 3 basal pores. Seed cinnamon, 0.7-0.8 $\times 0.3-0.35$ $\mathrm{mm}$, striate.

\section{Habitat and phenology}

Campanula peshmenii grows as a chasmophyte in the north side of carbonated calcareous (70-90 $\%$ limestone and $70-90 \%$ dolomite) rocks in the Meletbaşı Hamlet at 1800-2200 m (pers. comm.
M.Önal). Associated species at the type locality include: Hypericum malatyanum Peşmen, Silene odontopetala Fenzl, Parietaria judaica L., Prangos pabularia Lindl., and Silene caryophylloides Otth. subsp. stentorian (Fenzl) Coode \& Cullen. While flowering periods of this species are observed from early July to early September, its fruiting periods are observed from early August to late

\section{Conservation status}

Campanula peshmenii was evaluated as "Critically endangered" (CR) in The Red Data Book of Turkish Plants [13]. Area of occupancy of the species is limited to less than $10 \mathrm{~km}^{2}$, and total number of mature individuals is approximately 50-100. Therefore, this species should be evaluated as "Critically endangered" (CR B2ab(v)) according to the IUCN threat categories [14].

\section{ACKNOWLEDGEMENTS}

This study was supported by XV Regional Directorate of the Ministry of Forestry and Water Affairs of the Republic of Turkey along with Inönü University, Scientific Research Unit (Proj.No: 2013/49). The authors thank the curators of ANK, GAZI, HUB, and INU. Special thanks go to Dr. Murat Özabacı (İnönü University Scientific and Technological Research Centre) for SEM studies and to Prof. Dr. Mehmet Önal (İnönü University, Faculty of Engineering, Department of Mining) for geological comments.

\section{References}

1. T.J. Rosatti, The genera of Spherocleaceae and Campanulaceae in the Southeastern US. J. Arnold. Arboret., 67 (1986) 24-25.

2. T.G. Lammers, Campanulaceae. In: Kubitzki K. (ed.), World checklist and bibliography of Campanulaceae, Kew Publishing, (2007) 675.

3. J. Damboldt, Campanula L. In: P.H. Davis, et al (Eds.), Flora of Turkey and the east Aegean Islands. Vol. 6: 2-64. Edinburgh: Edinburgh University Press, (1978).

4. N. İkinci, Campanula L. In: Güner, A., Aslan, S., Ekim, T., Vural, M. \& Babaç., M.T. (eds.). Türkiye Bitkileri Listesi (Damarlı Bitkiler). Nezahat Gökyiğit Botanik Bahçesi ve Flora Araştırmaları Derneği Yayını, İstanbul, (2012) 303-310.

5. A. Güner, New records for the flora of Turkey and two new species from Anatolia, Notes R.B.G. Edinb., 41 (1983) 287.

6. D. Bridson, L. Forman, The Herbarium Handbook, (Third edition). Kew: Royal Botanic Garden (1998).

7. A. Kandemir, A new Campanula (Campanulaceae) from east Anatolia, Turkey. Nordic J. Bot. 25 (2007) 53-57.

8. A. İlçim, L. Behçet, A.Z. Tel, Campanula hacerae (Campanulaceae), a new species from Turkey, Ann. Bot. Fennici, 48 (2011) 507-510. 
9. H. Yıldırım, S.G. Şenol, Campanula alisan-kilincii (Campanulaceae), a new species from eastern Anatolia, Turkey, Turk J. Bot., 38 (2014) 22-30.

10. J. McNeill, F.R. Barrie, W.R. Buck, V. Demoulin, W. Greuter, D.L. Hawksworth, P.S. Herendeen, S Knapp, K. Marhold, J. Prado, W.F. Prud'homme van Reine, G.F. Smith, J.H. Wiersema, N.J. Turland, (Eds.) International Code of Nomenclature for algae, fungi, and plants (Melbourne Code): Adopted by the Eighteenth International Botanical Congress Melbourne, Australia, July 2011, Regnum Vegetabile, 154: Koeltz Scientific Books (2012).

11. I.P. Erkara, A. Ocak, S. Pehlivan, Pollen morphology of some Turkish Campanula spp. and their taxonomic value, Bengladesh J. Bot., 37 (2008) 33-42.
12. T.A. Akçın, Seed coat morphology of some Turkish Campanula (Campanulaceae) species and its systematic implications, Biologia, 64 (2009) 10891094.

13. T. Ekim, M. Koyuncu, M. Vural, H. Duman, Z. Aytaç, N. Adıgüzel (Eds.) Türkiye Bitkileri Kırmızı Kitabı (Pteridophyta ve Spermatophyta). TTKD ve Van 100. Yıl Üniversitesi Yayını, Ankara, (2000).

14. IUCN, IUCN Red List Categories and Criteria, Version 3.1". Second edition. IUCN Species Survival Commission, IUCN, Gland, Switzerland and Cambridge, UK. (2012). 